\title{
The Decline of Traditional Partisanship in Spanish Municipalities \\ Corruption, Inequality and Territorial Mobilisation
}

\author{
Eliška Drápalová, Hertie School of Governance, Berlin \\ drapalova@hertie-school.org \\ Davide Vampa, Aston University, Birmingham \\ d.vampa@aston.ac.uk
}

Word Count: 7937

Eliska Drapalova is a Postdoctoral fellow at Hertie School of Governance and FritzThyssen fellow (2016-2018). Eliska Drapalova is the PI of the project titled: Varieties of Performance of Local Governments in New and Old Democracies financed by the Fritz-Thyssen foundation. Her research interests include political economy, local government, corruption, comparative politics and experimental research on corruption.

Davide Vampa is Lecturer in Politics at Aston University, Birmingham. His research interests focus on the link between territorial party politics and public policy. He recently published a monograph on the regional politics of welfare in Italy, Spain and Great Britain (Palgrave Macmillan). He has also published articles and book chapters on multi-level social policy, changing local representation and populist parties in Western Europe 
Between 2008 and 2014, Spain experienced a severe recession, which had a deep impact on its political system. Scholars have mainly focused on transformations occurred at the national level but have neglected changing equilibria at the local level. This paper shows that in Spain the role of traditional parties as mediators of local interests has declined and suggests that they have to face increasing competition coming from citizens' lists, which label themselves as 'local' or 'non-partisan'. By relying on an original dataset and quantitative analysis, this paper aims to understand to what extent these new forces are influenced by other forms of territorial mobilisation represented by regionalist parties and whether corruption and inequality, two factors that are crucial in Southern European societies, may also explain part of their success.

Keywords: Spain, Local Governance, Local Lists, Corruption, Inequality, Regionalist Mobilisation,

\section{Introduction and Research Question}

Schattshneider's (1942) famous sentence 'democracy is unthinkable save in terms of parties' has been quoted by many scholars. This may not only be valid for the national dimension of politics but also for the local one. So far, studies have focused on the crisis or transformation of political parties by looking at changes in their organisation, communication strategies and linkages to society and the state (Bardi, Bartolini, and Trechsel 2014). However, less attention has been paid to changes in the 'territorial' function of parties. Indeed, parties have played a very important role as connectors of local and national interests and have facilitated the participation and integration of peripheral actors in cross-territorial policy-making processes (Bartolini 2005). An opposite process may have occurred over the last years. In some contexts, political parties have not only moved away from society and shifted towards the state, as 
highlighted by Katz and Mair (2009), but they may have also become less able to penetrate and control the local dimension of democracy.

Spain is a compelling test case since until the late 2000s it was regarded as a very stable political system where a small number of established political parties controlled the overwhelming majority of electoral preferences across all levels of government. Party competition used to be dominated by two large parties, the Spanish Socialist Workers' Party (PSOE), on the centre-left, and the People's Party (PP), on the centre-right. Yet, as it will be shown in the following sections, over the last years this picture of stability has changed dramatically and new actors have started challenging the primacy of political parties.

This article aims to understand whether and why partisanship has declined in Spanish municipalities. It tries to identify what factors have facilitated the emergence of local (citizens') lists that do not rely on traditional party labels and organisations. In particular, we focus on three factors that might explain this phenomenon: corruption, inequality and regionalist party mobilisation. We aim to understand whether episodes of corruption undermine the legitimacy of traditional political parties in local representative institutions. The link between inequality and changes in local representation has also been insufficiently studied. The key question is whether more inequality results in less partisan forms of local representation or, rather, strengthens the local role of parties that are connected to the national arena and place particular emphasis on 'statewide' issues of redistribution. Finally, we highlight the fact that regionalist and local mobilisations are two analytically distinct phenomena, since they focus on different territorial levels. Spain is a crucial case because the three factors mentioned above are all particularly relevant in its political and social system and are also characterised by significant territorial variation.

This article is structured as follows. We first provide a brief overview of the difference between partisanship and localism. This is followed by trends (from 2007 to 2015) and 
territorial variation in the strength of local lists across Spanish municipalities. We then present our theoretical framework that links corruption, inequality and regionalist mobilisation to the role of political parties at the local level. To test the theoretical framework, we rely on a quantitative analysis, which includes more than 600 Spanish municipalities and a number of 'control' variables.

In the last section, we present the results and conclude that the success of local lists is positively but weakly associated with previous episodes of corruption. Interestingly inequality is negatively associated with the rise of local lists. Therefore, while political parties that dominate the national scene might be only marginally damaged by local episodes of corruption, they might still retain their strength in contexts in which the gap between rich and poor is wider. Lastly, we discover that the success of local lists is unrelated to that of regionalist parties and this may point to tensions existing between 'localist' and 'regionalist' interpretations of territoriality, which are not necessarily complementary or coexisting.

\section{Partisanship and Localism: Setting the Framework}

The consolidation of democratic systems in the $20^{\text {th }}$ century was accompanied by the nationalisation of politics (Caramani 2004). During the phase of state consolidation and nation building competition between political parties was mainly shaped by the emergence and structuring of the 'class cleavage' (Bartolini 2000: 548-54), which was 'functional' rather than 'territorial.' Thus subnational politics increasingly reflected 'statewide' dynamics and parties were increasingly 'viewed as promoters of national politics down to the local level' (Aars and Ringkjøb 2005:162). Left-Right party competition reduced the importance of local-specific issues, which became secondary when compared to more general issues of redistribution and social justice (Dandoy and Schakel 2013; Hough and Jeffery 2006). The emergence of welfare systems also contributed to the centralisation and nationalisation of politics, as underlined by 
Ferrera (2005). As a result, local representation was increasingly dominated by parties that competed at all levels of government (from local to national).

Some countries, including Spain, maintained powerful regional institutions and were characterised by the persistence (and even strengthening) of regionalist parties that challenged the supremacy of statewide parties. However, regionalist parties are still 'parties', with a recognised leadership and organisational structures, which can be defined as 'cross-municipal' (i.e. they exist in more than one municipality). Their mobilisation is mainly based on the socalled 'centre-periphery', territorial cleavage or ethnic issues (Lipset and Rokkan 1967). Regionalist parties tend to focus more on the meso-level (Sharpe 1993) and frequently compete in national elections. In the case of Spain, regionalist parties have even been essential in the process of formation of national minority governments (Field 2016).

In this paper, we argue that the phenomenon of 'localism' is very different from any form of traditionally party-based politics. Some key characteristics of local lists are that they are 'solely locally organised'; that they compete for voters in 'one single local jurisdiction,' which is not formally and explicitly linked to any provincial, regional or national political organisation; and that they attend to local issues only (Aberg and Ahlberger 2015:813). Reiser and Holtmann (2008:7), also highlight that local lists 'perceive themselves as non-parties'.

For some authors, local lists reflect fundamental changes in the party system and erosion of established party identities (Mair, Müller, and Plasser 2004). The shrinking reputation of parties at the local level can be associated with the tendency of mainstream parties to govern rather than represent and to a weakening of ties with local communities. In these circumstances, local lists may play a 'brokerage role' (local interest representation) and provide single issue solutions (instead of appealing to long-term party loyalties). They may also profit from the 'elitist' profile and collective responsibility for bad government ascribed to political parties (Reiser and Holtmann 2008). 
The strength of local lists may be explained by a range of factors and previous research has mainly focused on socio-economic development, size of municipalities, time of elections and turnout (Ennser-Jedenastik and Hansen 2013; Aars and Ringkjøb 2005; Vampa 2016a). This paper considers two important factors that so far have been neglected by the literature: corruption and inequality. Additionally, our analysis assesses the relationship between two types of territorial mobilisation: regional and local.

\section{The Rise of Non-partisan Representation in Spanish Municipalities}

Declining local partisanship is accompanied by the emergence and strengthening of 'alternative' forms of political participation, which are not directly promoted by partisan (crossterritorial) organisations and focus almost exclusively on the municipal dimension. Therefore, our analysis centres on the success of local (non-partisan) lists, which is measured as the share of seats they won in the main representative institution existing at the local level: the municipal council. This can also be considered as an indicator of declining partisanship. We follow the same strategy adopted by Vampa $(2015 ; 2016 a)$ in his study on local representation in Italy. The data used for this study are taken from the archive of the Spanish Interior Ministry (http://www.infoelectoral.interior.es/min/).

We decided to focus on municipalities with a population of more than 10,000 inhabitants. We chose this threshold to select our cases for practical reasons as data are not available for some variables in smaller municipalities (particularly those on corruption and inequality). Additionally, small municipalities would have a very small number of council seats and this would heavily penalise small parties, thus negatively affecting the overall proportionality of the results and effective thresholds. This would risk distorting our results, since our dependent variable is measured as the share of seats won by local lists in the municipal council. 
In the Spanish case, the local lists' category includes citizens' groups and associations that compete for municipal representation but do not rely on the labels and direct organisational support of national (or regional) political actors. Lists that run only in one municipality and are only loosely, and not explicitly, associated with national parties or movements are still considered as 'local'. ${ }^{1}$ On the other hand, a list is categorised as partisan whenever it uses the label of the national or regional party. This is valid also for new parties, like Ciudadanos, which, unlike Podemos, decided to participate in local elections with its national label, thus following the example of more traditional parties such as the PSOE and PP.

Figure 1 shows that, over the period from 2007 to 2015, the average share of seats controlled by local lists in the main Spanish municipalities has increased from 5.6 to $16.7 \%$. As a result of this, it can be argued that the role played by political parties at the local level has declined, although they still control a high share of local representation. Particularly the sharp increase in local lists' representation in the 2015 election suggests that a process of transformation of local democracy may be under way and the ability (or willingness) of national party organisations to penetrate the local dimension of democracy is being gradually eroded. Therefore, Spain could move in the same direction as another Mediterranean country, Italy, in which local partisanship started to decline in the late 1990s and collapsed as a consequence of a deep economic and political crisis in the early 2010s (Vampa 2016a).

[Figure 1 near here]

Most interestingly, the increasing strength of local lists has not been homogeneous across municipalities. Table 1 shows that there is considerable territorial variation. For instance, in

\footnotetext{
${ }^{1}$ Podemos, created before 2014 EP elections, did not run in 2015 local elections but encouraged the creation of local civic lists.
} 
2015 the share of seats controlled by local lists ranged from 0 to $81 \%$, with a standard deviation of 14.7, which almost equalled the mean.

[Table 1 near here]

Lastly, whereas almost $50 \%$ of variation in success of local lists in 2011 is explained by success in 2007 (previous election), only $35 \%$ of variation in success of local lists in 2015 is accounted for by success in 2011. This figure is even smaller if we consider the association between 2015 and 2007 results (16\%). Figure 2 shows that, unsurprisingly, there is a positive correlation between local lists' share of council seats won in 2011 and 2015 but this correlation is far from perfect $(\mathrm{r}=0.59)$. Many municipalities that until 2011 were totally dominated by traditional party representation (with local lists scoring 0) now have a large share of councillors elected from lists without a party label. The most emblematic example is the capital Madrid, where until 2011 competition was between the two largest statewide parties (PSOE and PP), controlling between 80 and $90 \%$ of the seats (the rest being won by minor statewide parties, such as Izquierda Unida). It is therefore noticeable that in 2015 the civic list Ahora Madrid not only won representation for the first time but also managed to obtain more than one third of the seats in the municipal council and elect the city mayor. The list was created as a 'citizen platform' which, despite being supported by some left-wing groups, emerged from a bottomup process and did not explicitly identify with any political party. A similar phenomenon occurred in the second largest city of Spain, Barcelona, and many similar cases can be found in smaller municipalities.

Overall, we found that local lists managed to win seats in $81.9 \%$ of all the cases included in our sample and, within this group, they obtained representation for the first time in almost half of the cases. The scatterplot included in Figure 2 therefore does not show us the full story, since too many dots are on the y axis (meaning that local lists won seats in 2015 but not in 2011). 
The data indicate that 2015 is a particularly important year in the history of Spanish local representation, given the unprecedented success of new actors at the municipal level. The context in which this phenomenon occurred is that of a general crisis and restructuring of the Spanish party system. Yet this 'statewide' crisis was mediated by local factors. Three of these factors are discussed in the next section.

[Figure 2 about here]

\section{Theoretical Framework and Hypotheses}

\section{Corruption}

Corruption figures prominently among the causes of recent transformation and reconfiguration of party systems. The literature on corruption and voting behaviour concludes that corruption increases abstention and electoral volatility as the scandals alienate voters from established parties (Costas-Pérez, Solé-Ollé, and Sorribas-Navarro 2012; Winters and Weitz-Shapiro 2013). Some studies have tried to identify the circumstances under which citizens 'punish' corrupt politicians and switch their vote to a different party (Anduiza, Gallego, and Muñoz 2013). According to some authors this transfer of support is mediated by the type of corruption (Esaiasson and Muñoz 2014), the existence of alternative parties and their ideological proximity and integrity (Charron and Bågenholm 2016). However, much less has been written about the consequences that political corruption has on the type of representation or the creation of new political subjects (Hanley and Sikk 2016).

For dissatisfied voters, local lists can represent an alternative to corruption-riddled parties (Charron and Bågenholm 2016). Since corruption in Spain has affected mainly the traditional parties (PSOE and PP), it is expected that voters respond by voting for new and 'clean parties'. However, no study has considered the effect of corruption on the success of local lists. In the context of a corruption scandal, it may be easier for local lists to point to the 
weaknesses of the previous administration and attract outraged and dissatisfied voters. Moreover, since local lists are not linked to corrupt national parties and depend entirely on local electoral support, their accountability is believed to be more direct and thus greater (Tavits 2007).

On the other hand, corruption might not only influence the demand of citizens but also the offer of new political subjects. Research has shown that corruption and austerity policies are linked with large mobilization and protests (della Porta 2015). In this way, corruption might induce dissatisfied citizens to create an own political subject. This tends to be easier at the local level where the material and personnel resources needed for the campaign are lower. According to our dataset, $37 \%$ of the municipalities experienced at least one corruption scandal before the 2015 elections.

We can thus hypothesize that:

H1. Previous episodes of corruption are positively associated with support for local lists

\section{Inequality}

Voting behaviour may also be affected by the context of inequality (Bartels 2010). This, in turn, is likely to affect the composition of representative intuitions. There is considerable controversy regarding the interconnections between citizens' behaviour, political representation and inequality in the distribution of economic resources (Stokes et al. 2013). In the literature, inequality is associated with low electoral participation, especially among the poor (Beramendi and Anderson 2008; Scervini and Segatti 2012) and higher preferences for parties that support redistribution (Moene and Wallerstein 2001; Pontusson and Rueda 2010). This literature links inequality to the more traditional 'left-right' political cleavage. As a 
consequence, one may expect that, in those contexts in which inequality is higher, the electoral competition focuses on issues of social redistribution, rather than on local/territorial issues. Literature does not provide any substantial evidence that there should be a positive relationship between inequality and electoral support for non-partisan, locally-focused actors.

In sum, higher inequality within a municipality may lead to the major incidence of traditional cleavages (left-right) and favour traditional parties, which are also represented in the national parliament and compete to control the national government. These parties have a stronger impact on the redistribution of resources than local lists, which are active only at the municipal level. This would be perceived by both poor and wealthy voters, who would tend to support national ('statewide') parties to either promote or prevent radical redistribution of resources through taxation.

On the contrary, low levels of inequality may foster a sense of 'community' and social cohesion. This may also favour the emergence of local 'developmental coalitions' defined by Keating (1997) as 'place-based inter-class coalitions of political, economic and social actors devoted to the economic development in a specific location'. Bartolini (2005) highlights that when the developmental goal becomes more important than the redistributive goal, local communities tend to enhance unified representation of local interests and downplay partisan divisions. Therefore, we hypothesize that:

H2. Inequality is negatively associated with the success of non-partisan, local lists.

\section{The link with regionalist mobilisation}

We argued that local lists are different from regionalist parties because they focus on the local rather than 'meso' level of government. However, both phenomena are linked to the process of 
'territorialisation' and 'de-nationalisation' of politics. As a consequence, an association might exist between them.

As underlined by Vampa (2016a) in his study of the Italian case, regionalist parties may have two opposite effects on the local political environment and the rise of local lists. On the one hand, their focus on the sub-national dimension of government may challenge the role of statewide parties and weaken them. In a context of territorial 'de-structuring' and 'denationalisation' of party competition, which, as highlighted by Emanuele (2015), is accompanied by party system 'de-institutionalisation', local lists may have more opportunities to succeed. Therefore, there might be a positive relationship between the existence of regionalist parties and local lists. This is what Vampa (2016a: 587) defines as 'contagion' effect, since the strengthening of regionalist parties also results in the flourishing of local lists. On the other hand, the rise of regionalist parties may hinder the success of local lists. Indeed, because of their territorial nature and focus on the sub-national dimension of politics, regionalist parties may be more successful than statewide parties in integrating and representing local interests. Therefore, in those contexts in which regionalist parties are already strong, local lists might not be needed. This is defined by Vampa as 'replacement' effect and his findings suggest that in the Italian case this has been the clearly dominant effect: in those municipalities with strong regionalist parties, local lists have struggled to gain institutional representation.

We test both 'contagion' and 'replacement' effects in the Spanish context. Therefore:

H3a. The success of regionalist parties has a positive effect on the rise of local lists (contagion effect)

H3b. The success of regionalist parties has a negative effect on the rise of local lists (replacement effect) 
Spain is characterised by strong regional governments and regionalist parties. Therefore, one would expect that a similar 'replacement' effect has occurred in the Spanish context. The absence of such effect would suggest that it is not possible to detect a consistent relationship between regionalism and localism (even in two similar countries) and, therefore, the links between the two phenomena should be better investigated by future research.

\section{The Spanish Context: Local institutions and Electoral system}

Spanish municipalities use two different electoral models depending on the municipality size (Alba and Navarro 2003:208). In all municipalities with more than 250 inhabitants, electoral competition takes place between closed and blocked lists. The city councillors are elected by applying the D'Hondt formula. To access the distribution of seats, it is necessary to reach the threshold of $5 \%$ of the valid votes. The mayor is elected indirectly by the absolute majority of councillors. The municipal elections are held every four years. Following the Ley Orgánica de Régimen Electoral General (LOREG) 13 of 17 Autonomous communities harmonised their electoral calendars and now hold local and regional elections at the same time (Martínez Fuentes and Villodres 2010:150).

\section{Data and Operationalization}

Table 2 provides a preliminary analysis of how the success of local lists is related to corruption, inequality and the political legacy of regionalism. Data on corruption were collected by merging the dataset by Martín et al. (2012) and Drapalova (2016) and are based on an analysis of reports of corruption in the main national and regional Spanish newspapers. Corruption is coded 1 when the news reported that the city had a corruption scandal between 2007 and 2015 and 0 otherwise. Although this operationalisation has some limitations, it is based on the 
(plausible) argument that voters learn about corruption episodes in their city via local and/or national news.

We operationalise and measure inequality by using the Gini coefficient, ranging from 0 (perfect equality) to 100 (perfect inequality). Gini scores are taken from the dataset elaborated by Miriam Hortas-Rico and Jorge Onrubia (2014). ${ }^{2}$ In Table 2 we split the 665 municipalities into two categories with low and high levels of inequality (below and above the median).

Finally, the legacy of regionalist parties is measured by considering the share of seats won by these parties in the previous local elections. Also in this case, we split municipalities into two categories, weak and strong legacy of regionalism (again we used the median as a reference value).

It can be noted that, on average, local lists managed to win a larger share of seats in municipalities that experienced corruption than in all the others. The difference is 3.32 percentage points and it is statistically significant at any conventional level. It is interesting to note than in the previous election in 2011 the difference between these two groups was much smaller and not statistically significant. A significant difference also emerges if we compare municipalities with low and high levels of inequality. In this case, local lists seem more successful in less unequal municipalities. The difference is almost 3 percentage points and is statistically significant. Again, the gap between the two groups seems to have significantly increased in the critical election of 2015 as it was negligible in 2011, when local lists were, on average, much weaker. This seems to confirm the hypothesis that a more even distribution of economic resources is positively correlated with localist tendencies and reduces traditional partisan competition. Lastly, there does not seem to be a clear link between the strength of local lists and regionalist mobilisation. In 2015, the difference between municipalities with a strong

\footnotetext{
${ }^{2}$ Gini coefficients are available for 665 out of 752 municipalities.
} 
regionalist legacy and those where regionalist parties have not succeeded is rather small and not statistically significant (in 2011 it is barely significant at the 0.1 level).

[Table 2 near here]

Yet these are just preliminary results and more accurate analysis is needed in order to systematically assess the link between the 2015 striking success of local lists, and the three key independent variables identified in this paper. For this reason, the next section develops a multivariate regression model, which includes a number of key control variables. The regression analysis will focus on $2015^{3}$, the year in which local lists made significant inroads into Spanish municipalities.

\section{Control variables}

Before moving to the analysis, we discuss possible alternative explanations for the success of local lists in 2015. First we control for population size. Research showed a stronger representation of local lists in smaller municipalities (Ennser-Jedenastik 2015; Vampa 2016a). Local lists and neighbour movements might be stronger in small towns, where citizens' collective action does not need a lot of organisational support from political parties and where local representation tends to be dominated by local issues. Additionally, mainstream parties might operate and focus strategically on larger towns and regional and provincial capitals that are important for their electoral performance in national elections. Since the overall number of municipal seats increases with population, this variable may have an impact on the proportionality of seat allocation and this should be taken into account when explaining the

\footnotetext{
${ }^{3} \mathrm{We}$ also focus on 2015 because data for control and independent variables in previous election rounds have a high number of missing data.
} 
success of local lists in winning municipal representation. The size of the municipality is measured as the number of inhabitants (thousands) registered in a municipality (we use data from municipal registers, retrieved from www.ine.es). We use the log transformation of this variable due to its highly-skewed distribution.

Moreover, socio-economic development might have influenced the emergence of local lists. Vampa (2015; 2016a) finds a relationship between socio-economic development and the success of local lists or anti-establishment movements in Italy. Inglehart and other scholars, argue that higher levels of socio-economic development bring about change in values and type of political participation (Inglehart and Welzel 2005). Communities with post-material values are in favour of unconventional political participation (protests and petitions) and support direct citizens' input in government decisions (Cantijoch and San Martin 2009).

Similarly, Robert Putnam has suggested that communities with a higher level of social capital are characterised not only by higher levels of economic development but also by more vigilant and politically active citizens (Putnam 1994). This factor might affect forms of representation because local lists are often constituted by the neighbours' movements or civic associations and, therefore, their strength may be expected to be associated with levels of social capital, and active citizens' engagement within their communities (Kapucu 2011).

The socio-economic development of a municipality is measured by per capita gross income (thousands of euros). The data refer to 2015 and are taken from the official database of the Tax Administration Agency (Agencial Tributiaria, https://www.agenciatributaria.es). Again, since the variable is highly skewed, we use its log transformation. Social capital is positively related to socio-economic development, as underlined by Putnam (1994). So we could use local income per capita also as a proxy of social capital since here we are not interested in uncovering the causal link between civicness and socio-economic development but we just assume that they coexist. An additional indicator used is internet access, which we 
measure by dividing the number of connections by the population and multiplying it by 100 . Therefore, a score of 0 means that no one has access to the internet, whereas a score of 100 means that, on average, each inhabitant of a municipality has an internet connection. This measure was retrieved from the Economic Yearbook of Spain compiled by caixa.es (www.caixa.es/estudios). It is an alternative to newspaper readership or number of association (unavailable at city level) and has already been used by other authors (Mungiu-Pippidi 2014). Internet access is also relevant for the emergence of new, anti-establishment movements and horizontal networks of citizens. The cases of the 5 Star Movement in Italy and Podemos in Spain clearly show the importance of social media in promoting 'new' forms of political participation, which go beyond more traditional party structures (Hartleb 2013).

Finally, we control for two political variables, which might have affected the emergence of local lists. In the case of Spain, a link seems to exist between the creation of local lists and political mobilisation on the more radical (and populist) Left. Podemos clearly exemplifies this phenomenon, since this left-wing political movement decided not to run directly in local elections but, instead, support some local lists (for example, in Barcelona). Also, Izquierda Unida (IU) formed alliances with 'ad hoc citizens' platforms' and, in many municipalities, did not use its party label (Rodon and Hierro 2016:346-347). Therefore, in some cases, local lists might be 'partisan lists in disguise' (Vampa 2016a:583) and their results might be inflated by the influence of Podemos or IU in local elections. This might in turn influence (and distort) our results. Therefore we decided to control for the strength of IU in previous local elections (the share of seats that the party won in 2011). We also control for the share of the vote won by Podemos. As this political movement did not officially run in the 2015 local elections (nor in 
the 2011 elections), we use the municipal vote share that Podemos obtained in the previous closest election, the European Parliament (EP) election in $2014 .^{4}$

\section{Results}

To test our hypotheses, we employ a multivariate linear regression model having the share of seats won by local lists in 2015 as the dependent variable. Table 3 shows the magnitude and significance of the coefficients of the independent and control variables listed above. We use robust standard errors in order to allow for the presence of heteroscedasticity ${ }^{5}$. Model 2 includes a variable measuring local lists' success in the previous election (2011). We therefore follow the procedure adopted by Vampa (2016a) in his analysis of Italian local lists. Although we found that significant part of the variation in 2015 is not explained by variation in 2011, this additional variable can tell us something about the effect of 'legacy' on the more recent success of local lists.

It can be seen that only one of the three hypotheses presented in this paper is clearly confirmed in both models. The recent success of local lists seems to have been more pronounced in those municipalities characterised by lower levels of inequality. The coefficient of Model 1 suggests that holding all the other variables constant, a 10 point increase in inequality (on the $0-100$ scale of the Gini coefficient) would correspond to an average decrease of 2.9 percentage points in the share of seats won by local lists. This is a considerable effect since, as shown in the descriptive statistics table in the appendix, in our sample Gini scores range from 12.92 to 64.25 . The coefficient is statistically significant at the 0.1 level. When adding the legacy variable (Model 2), its magnitude does not change substantially but its

\footnotetext{
${ }^{4}$ We consider Podemos vote share in the EP elections as a good proxy, both elections are close to each other (EP was first) and both are considered elections with 'second-order' effects.

${ }^{5}$ The use of robust standard errors is appropriate since they do not substantially differ from classical standard errors (King and Roberts 2015).
} 
statistical significance increases. Unsurprisingly, also the legacy variable has a significant effect.

As expected by H1, the corruption variable is positively associated with local lists' success. Corruption is likely to reduce citizens' trust in traditional political actors and encourage them to form and support independent citizens' platforms. In model 1 the coefficient is statistically significant and suggests that in municipalities that experienced episodes of corruption, local lists' representation is expected to increase, on average, by 2.7 percentage points. When we take into account 2011 results, corruption remains positive although it loses statistical significance. One explanation is that our dataset also includes corruption scandals occurred before 2011 and they might have had an effect already in that year.

Finally, the coefficient of 'regionalist mobilisation' is very small and not statistically significant at any conventional level. This seems to suggest that neither the 'replacement' nor the 'contagion' effects suggested by $\mathrm{H} 3 \mathrm{a}$ and $\mathrm{H} 3 \mathrm{~b}$ are occurring in the Spanish local context.

[Table 3 near here]

The values of the population size coefficient are inconsistent between the two models, Model 1 suggests that the effect of this variable is negative and significant, while, once the legacy variable is included in Model 2 it becomes positive but not significant. One possible explanation for this result is that in 2011 local lists were mainly a phenomenon associated with small municipalities (and indeed if we regress legacy on the population log the coefficient is negative and statistically significant) and in 2015 they spread to larger municipalities.

Per capita income, a proxy for socio-economic development, is positively associated with the strength of local list representation and its coefficient is statistically significant in both models. The sign of the internet connection variable is inconsistent but it is not statistically significant in either model. Again, the inclusion of the legacy variable may explain this. Internet 
diffusion may have had an earlier effect on local lists' success in 2011 and no further effect in the following election. Additionally the two 'socio-economic' variables seem to be strongly correlated $(r=0.5)$ and the effect of access to internet might have been 'absorbed' by the income variable. Indeed, when excluding income, the internet variable becomes consistently positive and statistically significant at 0.01 . Once we take these considerations into account, the general finding is that Spanish local lists have been more successful in more socio-economically developed and better connected municipalities. Yet evidence from another similar country, Italy, suggests the opposite (Vampa 2016a). It seems that, whereas in Italy more or less traditional parties have managed to maintain their control of the administration of richer municipalities, in Spain they have remained more powerful in poorer ones. More in-depth (qualitative) analyses should try to corroborate this finding and explain the discrepancy between Italian and Spanish results by focusing on the different types of incentives and challenges faced by party organisations in the two countries.

Interestingly the Podemos variable has positive and statistically significant coefficients in both models (whereas IU has no statistically significant effect). This result confirms the fact that some sectors of the new 'populist' Left actively encouraged the creation of local lists, thus deciding not to use their partisan label. This also suggests the existence of an important phenomenon of 'denationalisation' of local politics, in which the local and national dimensions of partisanship (at least in some sectors of the party system) become increasingly separated (what Katz and Mair [2009: 761], define as 'stratarchy'). By accounting for this phenomenon, we also managed to assess the effect of our key independent variables - corruption, inequality and regionalism - regardless of the political influences of movements and parties, which may be less focused on purely territorial issues but, at the same time, reject traditional party politics and labels. Only inequality seems to retain its direct (negative) effect on the success of local lists. It is interesting to note that the performance of Podemos in the EP elections is significantly 
better in those municipalities which experienced episodes of corruption. ${ }^{6}$ Therefore this movement might have acted as antervening variable between corruption and the emergence of more 'politicised' local lists. This would explain why the effect of corruption is less consistent than expected in the multiple regression analysis.

\section{Discussion and Conclusion}

The results presented in this paper point to the decline of party labels in the Spanish local arena. 2015 was a critical year for Spanish local democracy because it was marked by the electoral breakthrough of local lists. Yet, their success was not territorially uniform and, may be linked to different factors. We focused on three key variables, which might explain some of the variation. We found that inequality is consistently and negatively associated with the rise of these lists. As expected by our hypothesis, in those contexts in which inequality is higher, partisan issues of social redistribution may be more salient than local/territorial ones, and this may in turn sustain competition between more traditional centre-left and centre-right political parties, which also dominate politics at the national level. This finding contradicts the conclusions from previous research by Aberg and Ahlberger (2015) on non-partisan local lists in Sweden where local lists increase support as a result of welfare state retrenchment and inequality in local communities. Contrary to this, we find an opposite trend, since in municipalities with higher inequality national parties seem still dominant, while local lists are significantly weaker.

The link between corruption and the rise of local lists is less clear. Our preliminary analysis showed that indeed local lists seem to have been significantly more successful in contexts in which political parties have been discredited by corruption scandals. However, when we control for the 'legacy' variable the effect of corruption drops considerably. This may

\footnotetext{
${ }^{6}$ The average result of Podemos was $6.9 \%$ in municipalities which did not experience corruption and $8.6 \%$ in those that did.
} 
be due to the fact that our corruption variable includes episodes occurred from 2007 to 2015 and, therefore, corruption might have already had an effect in 2011. Another explanation for this is that the effect of corruption on the emergence of local lists is mediated by the emergence of anti-establishment actors, like Podemos, which are clearly opposed to traditional party politics but do not rely on a purely 'localist' platform.

Lastly, localism and regionalism do not seem to be linked to each other. Vampa (2016a) found that in Italy local lists tend to be weaker in those contexts in which regionalist parties are stronger. He calls it 'replacement' effect since regionalist parties are able to incorporate successfully some of the territorial demands coming from the local level. In the case of Spain, no substantial and statistically significant effect is found in the 'critical' election of 2015. This points to the fact that territoriality may be represented in different ways at local and regional levels. Spanish regionalist parties have not always been more focused on the local dimension of politics than statewide parties and, when in government, they have often preferred to promote forms of 'regional' centralism, which may not be very responsive to local demands ${ }^{7}$ (Vampa 2016b). Therefore, treating localism and regionalism as part of the same phenomenon of 'rising territorial politics' may be misleading and may overlook significant discrepancies and tensions in the way the concept of territoriality is interpreted and promoted by actors at different levels of sub-state government (municipal, provincial, regional). Future research should try to disentangle the set of relations existing between these actors, thus going beyond the study of centre-periphery relations based on the simple dichotomy between national and sub-national dimensions (with regional and local dimensions merged into the latter).

Spain is far from being an isolated case. Scholars have observed the emergence of similar phenomena in the local political arenas of various countries, mainly in Eastern and

\footnotetext{
${ }^{7}$ For instance, as shown by Vampa (2016b: 123) Convergència i Unió (CiU), ruling Catalonia since the late 1970s, sought to dominate the policy making process of the Autonomous Community by limiting the autonomy of provinces and municipalities.
} 
Southern Europe, such as Italy or Poland but also in countries with stronger partisan traditions such as the UK or Scandinavian countries (Sweden and Norway). A question that needs to be addressed is whether local groups in different national contexts are part of the same phenomenon or they are driven by different, and perhaps country-specific, logics. The comparison between Spain and Italy suggests that even in apparently similar countries, the origins and role of local lists may differ greatly. In Italy, local lists are predominant in rural and poorer areas. Indeed, they have become a reservoir of votes controlled by local notables (micro-notabilato), who no longer depend on traditional party structures to secure their control of local institutions and resources. Additionally, it would be interesting to compare 'core' and 'peripheral' European countries to understand whether cross-country differences in the characteristics of local representation are explained by variation in the general state of public finances and the fiscal constraints. Lastly, after understanding the causes of their success, further research should also assess the effects of new local actors on public policy, delivery of public goods, citizens' participation and local government performance.

\section{References}

AARS, JACOB, and HANS-ERIK RINGKJ ØB. 2005. Party Politicisation Reversed? Non-Partisan Alternatives in Norwegian Local Politics. Scandinavian Political Studies 28(2): 161-181.

ABERG, MARTIN, and CHRISTER AHLBERGER. 2015. Local Candidate Lists: Historical Artefacts or a Novel Phenomenon? A Research Note. Party Politics 21(5): 813-820.

ALBA, CARLOS, and CARMEN NAVARRO. 2003. Twenty-Five Years of Democratic Local Government in Spain. In Reforming Local Government in Europe. Norbert Kersting and Angelika Vetter, eds. Urban and Research International, 4. VS Verlag für Sozialwissenschaften, pp. 197-220.

ANDUIZA, EVA, AINA GALLEGO, and JORDI MUÑOZ. 2013. Turning a Blind Eye Experimental Evidence of Partisan Bias in Attitudes toward Corruption. Comparative Political Studies 46(12): 1664-1692.

BARDI, LUCIANO, STEFANO BARTOLINI, and ALEXANDER TRECHSEL. 2014. Party Adaptation and Change and the Crisis of Democracy. Party Politics 20(2): 151-159. 
BARTELS, LARRY M. 2010. Unequal Democracy: The Political Economy of the New Gilded Age. New York; Princeton, N.J.: Princeton University Press.

BARTOLINI, STEFANO. 2000. The Political Mobilization of the European Left 1860-1980. Cambridge; New York: Cambridge University Press.

BARTOLINI, STEFANO.2005. Restructuring Europe. Centre Formation, System Building and Political Structuring between the Nation State and the EU. Oxford: Oxford University Press.

BERAMENDI, PABLO, and CHRISTOPHER J. ANDERSON. 2008. Democracy, Inequality, and Representation in Comparative Perspective. New York: Russell Sage Foundation.

CANTIJOCH, MARTA, and JOSEP SAN MARTIN. 2009. Postmaterialism and Political Participation in Spain. South European Society and Politics 14(2): 167-190.

CARAMANI, DANIELE. 2004. The Nationalization of Politics: The Formation of National Electorates and Party Systems in Western Europe. Cambridge: Cambridge University Press.

CHARRON, NICHOLAS, and ANDREAS BÅGENHOLM. 2016. Ideology, Party Systems and Corruption Voting European Democracies. Electoral Studies 41: 35-49.

COSTAS-PÉREZ, ELENA, ALBERT SOLÉ-OLLÉ, AND PILAR SORRIBAS-NAVARRO. 2012. Corruption Scandals, Voter Information, and Accountability. European Journal of Political Economy 28(4): 469484.

DANDOY, R., and ARJAN H. SCHAKEL. 2013. Regional and National Elections in Western Europe. Territoriality of the Vote in Thirteen Countries. Houndmills: Palgrave Macmillan.

DRAPALOVA, ELISKA. 2016. Good Apples on Bad Trees: Explanation of Variation in Corruption Level in Southern European Local Government. Unpublished doctoral dissertation, European University Institute.

EMANUELE, VINCENZO. 2015. Vote (de-)nationalisation and Party System Change in Italy (19482013). Contemporary Italian Politics 7(3): 251-272.

ENNSER-JEDENASTIK, LAURENZ. 2015. The Politicization of Regulatory Agencies: Between Partisan Influence and Formal Independence. Journal of Public Administration Research and Theory: muv022.

ENNSER-JEDENASTIK, LAURENZ, and MARTIN EJNAR HANSEN. 2013. The Contingent Nature of Local Party System Nationalisation: The Case of Austria 1985-2009. Local Government Studies 39(6): 777791.

ESAIASSON, PETER, and JORDI MUÑOZ. 2014. ROBA PERO HACE? An Experimental Test of the Competence-Corruption Trade-off Hypothesis in Spain and Sweden. QoG Institute Working Papers. http://qog.pol.gu.se/digitalAssets/1474/1474905_2014_02_essaiasson_jordi.pdf.

FERRERA, MAURIZIO. 2005. The Boundaries of Welfare: European Integration and the New Spatial Politics of Social Protection. Oxford: Oxford University Press. 
FIELD, B. N. 2016. Why Minority Governments Work: Multilevel Territorial Politics in Spain. Basingstoke ; New York: Palgrave Macmillan.

HANLEY, SEÁN, and ALLAN SIKK. 2016. Economy, Corruption or Floating Voters? Explaining the Breakthroughs of Anti-Establishment Reform Parties in Eastern Europe. Party Politics 22(4): 522-533.

HARTLEB, FLORIAN. 2013. Anti-Elitist Cyber Parties? Journal of Public Affairs 13(4): 355-369.

HORTAS-RICO, MIRIAM, and JORGE ONRUBIA. 2014. Renta Personal de Los Municipios Españoles y Su Distribución, Años 2004 a 2006 y Actualización de 2007. FEDEA, Estudios sobre la Economía Española - 2016/11.

HOUGH, DAN, and CHARLIE JEFFERY. 2006. Devolution and Electoral Politics. Manchester: Manchester University Press.

INGLEHART, RONALD, and CHRISTIAN WELZEL. 2005. Modernization, Cultural Change, and Democracy: The Human Development Sequence. Cambridge ; New York: Cambridge University Press.

KAPUCU, NAIM. 2011. Social Capital and Civic Engagement. International Journal of Social Inquiry 4(1): 23-43.

KATZ, RICHARD S., and PETER MAIR. 2009. The Cartel Party Thesis: A Restatement. Perspectives on Politics 7(4): 753-766.

KEATING, MICHAEL. 1997. The Political Economy of Regionalism. In The Political Economy of Regionalism. Edited by Michael Keating and J. Loughlin. London: Frank Cass. pp. 19-43.

KING, GARY, and MARGARET E. ROBERTS. 2015. How Robust Standard Errors Expose Methodological Problems They Do Not Fix, and What to Do About It. Political Analysis 23(2): 159-179.

LIPSET, SEYMOUR MARTIN, and S. ROKKAN. 1967. Cleavage Structures, Party Systems and Voters' Alignments: An Introduction'. In Party Systems and Voter Alignments: A Cross-National Perspective, edited by Seymour Martin Lipset and S. Rokkan. New York: Free Press. pp. 1-64.

MAIR, PETER, WOLFGANG C. MÜLLER, and FRITZ PLASSER. 2004. Political Parties and Electoral Change: Party Responses to Electoral Markets. SAGE.

MARTÍN, VÍCTOR O. MARTÍN, LUIS M. JEREZ DARIAS, and RAMÓN PERÉZ GONZALES. 2012. Aproximación a una Geografía de la Corrupción Urbanística en España. Ería 1(87): 5-18.

MÉNDEZ, RICARDO, LUIS D. ABAD, and CARLOS ECHAVES. 2015. Atlas de la Crisis. Barcelona: Tirant lo Blanch.

MOENE, KARL OVE, and MICHAEL WALLERSTEIN. 2001. Inequality, Social Insurance, and Redistribution. The American Political Science Review 95(4): 859-874.

MUNGIU-PIPPIDI, ALINA (ed). 2014. The Anticorruption Frontline, vol.2. Berlin: Barbara Budrich Publishers. 
PONTUSSON, JONAS, and DAVID RUEDA. 2010. The Politics of Inequality: Voter Mobilization and Left Parties in Advanced Industrial States. Comparative Political Studies 43(6): 675-705.

DELLA PORTA, DONATELLA. 2015. Social Movements in Times of Austerity: Bringing Capitalism Back Into Protest Analysis. John Wiley \& Sons.

PUTNAM, ROBERT D., ROBERT LEONARDI, and RAFFAELLA Y. NANETTI. 1994. Making Democracy Work: Civic Traditions in Modern Italy. New Jersey: Princeton University Press.

REISER, MARION, and EVERHARD HOLTMANN. 2008. Farewell to the Party Model?: Independent Local Lists in East and West European Countries. Springer Science \& Business Media.

RODON, TONI, and MARÍA JOSÉ HIERRO. 2016. Podemos and Ciudadanos Shake up the Spanish Party System: The 2015 Local and Regional Elections. South European Society and Politics 21(3): 339-357.

SCERVINI, FRANCESCO, and PAOLO SEGATTI. 2012. Education, Inequality and Electoral Participation. Research in Social Stratification and Mobility 30(4). Consequences of Economic Inequality: 403-413.

SCHATTSCHNEIDER, ELMER ERIC. 1942. Party Government. New Brunswick, U.S.A and London, UK: Transaction Publishers.

SHARPE, LAURENCE J. 1993. The Rise of the Meso Government in Europe. London: SAGE Publications Ltd.

STOKES, SUSAN C., THAD DUNNING, MARCELO NAZARENO, and VALERIA BRUSCO. 2013. Brokers, Voters, and Clientelism: The Puzzle of Distributive Politics. Cambridge University Press.

TAVITS, MARGIT. 2007. Clarity of Responsibility and Corruption. American Journal of Political Science 51(1): 218-229.

VAMPA, DAVIDE. 2015. Local Representative Democracy and Protest Politics: The Case of the FiveStar Movement. Contemporary Italian Politics: 1-19.

-- 2016a. Declining Partisan Representation at the Sub-National Level: Assessing and Explaining the Strengthening of Local Lists in Italian Municipalities (1995-2014). Local Government Studies 42(4): 579-597.

-- 2016b. The Regional Politics of Welfare in Italy, Spain and Great Britain. Basingstoke: Palgrave Macmillan.

WINTERS, MATTHEW S and REBECCA WEITZ-SHAPIRO. 2013. Lacking Information or Condoning Corruption: When Do Voters Support Corrupt Politicians? Comparative Politics 45(4): 418-436. 


\section{Appendix.}

Summary statistics for independent variables and controls.

\begin{tabular}{|c|c|c|c|c|c|}
\hline Variable & Observations & Mean & Std. Dev. & Min & Max \\
\hline Local lists 2015 & 752 & 16.72722 & 14.74379 & 0 & 80.95238 \\
\hline \multicolumn{6}{|l|}{$\begin{array}{l}\text { Independent } \\
\text { variables }^{8}\end{array}$} \\
\hline Inequality & 665 & 44.94101 & 04.79879 & 12.918 & 64.251 \\
\hline $\begin{array}{l}\text { Regionalist } \\
\text { mobilisation }\end{array}$ & 752 & 17.91895 & 22.68687 & 0 & 100 \\
\hline \multicolumn{6}{|l|}{ Controls } \\
\hline $\begin{array}{l}\text { Population size } \\
\text { (thousands } \\
\text { inhab.) }\end{array}$ & 752 & 49.38283 & 148.0628 & 10.008 & 3233.527 \\
\hline $\begin{array}{l}\text { Per capita gross } \\
\text { income } \\
\text { (thousands } \\
\text { euros) }\end{array}$ & 699 & 19.20003 & 4.074701 & 11.863 & 51.002 \\
\hline $\begin{array}{l}\text { Internet } \\
\text { connections }\end{array}$ & 752 & 25.16123 & 5.03508 & .1155777 & .4053147 \\
\hline Local lists 2011 & 752 & 7.15781 & 11.79441 & 0 & 84.61539 \\
\hline Izquierda Unida & 752 & 6.19736 & 8.67524 & 0 & 70.58824 \\
\hline Podemos & 746 & 7.57782 & 3.29832 & 00.9243 & 21.09754 \\
\hline
\end{tabular}

${ }^{8}$ Corruption is a dichotomous variable coded 1 when news reported that the city had a corruption scandal between 2007 and 2015 and 0 otherwise (data for four cases out of 752 are missing). In our sample 37, 5\% cities have experienced corruption incident. Standard deviation is 48.46191 . 
Figure 1 Average share of council seats controlled by local lists from 2007 to $2015(\mathrm{~N}=752)$

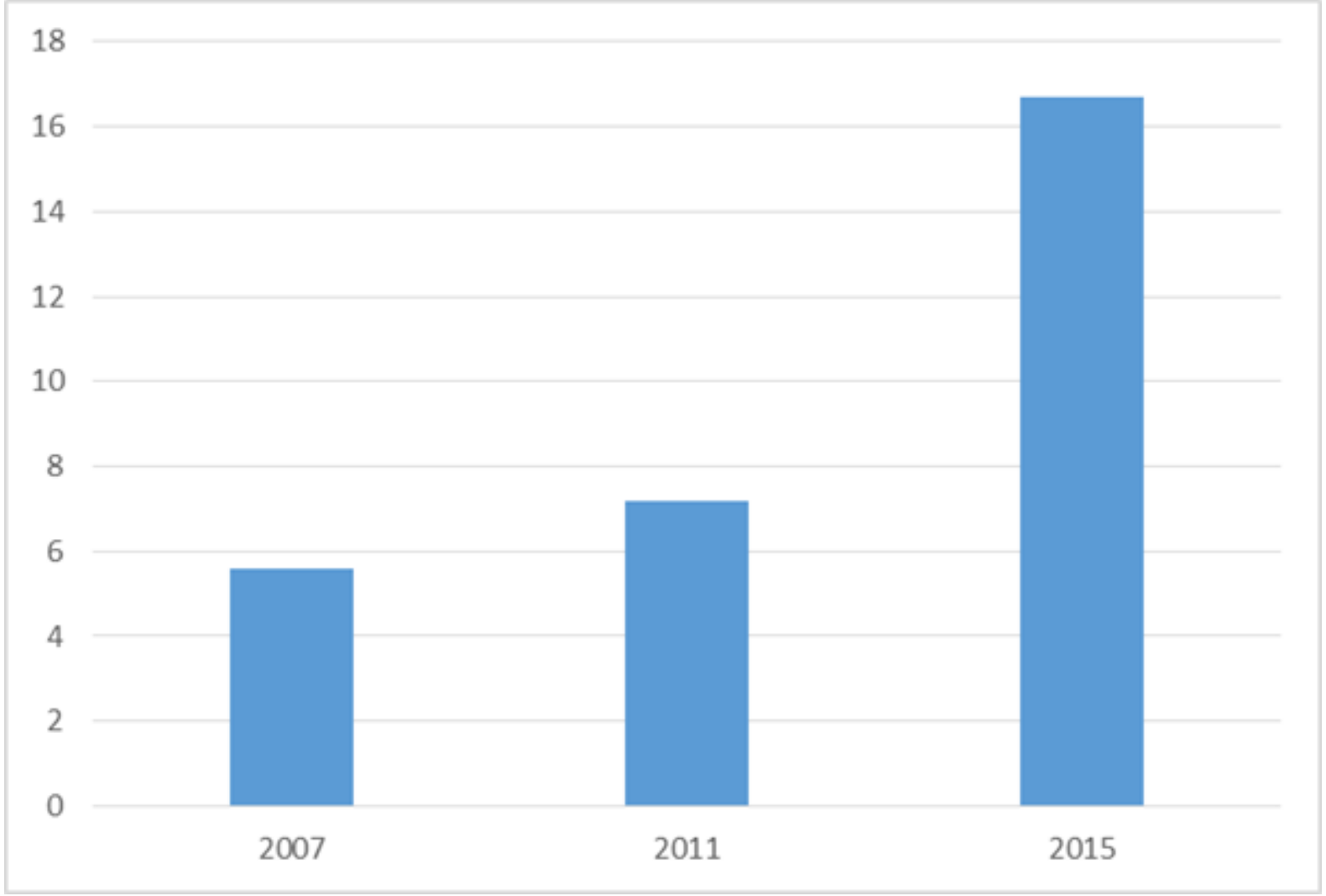


Figure 2. Correlation between local lists' success in 2011 and 2015

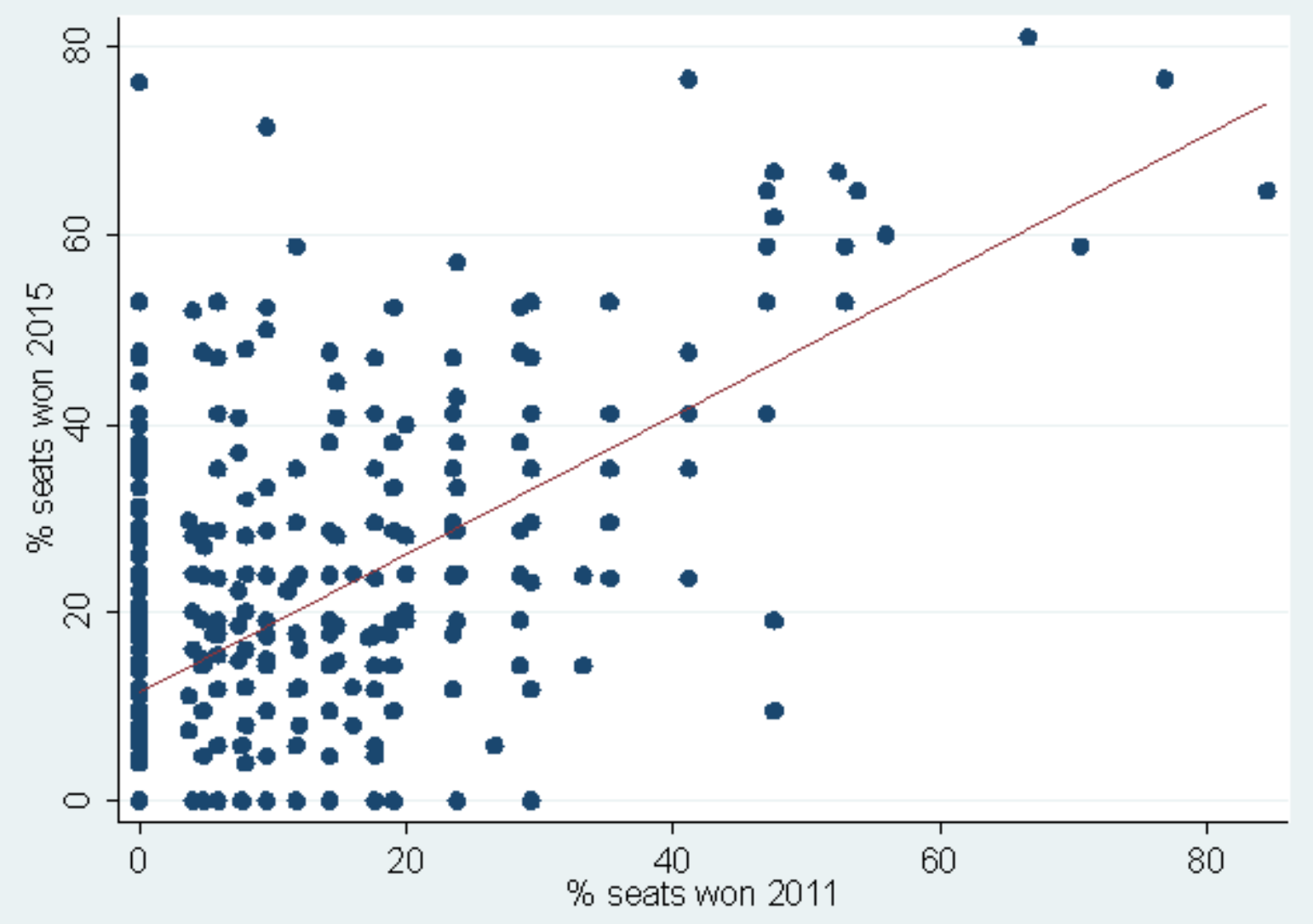


Table 1 The evolution of local lists from 2007 to 2015. Descriptive Statistics.

\begin{tabular}{|c|c|c|c|c|}
\hline & Mean & Minimum & Maximum & $\begin{array}{c}\text { Standard } \\
\text { Deviation }\end{array}$ \\
\hline $\begin{array}{c}\text { Local lists } \\
2007\end{array}$ & 5.6 & 0 & 76.9 & 11.3 \\
\hline $\begin{array}{c}\text { Local lists } \\
2011\end{array}$ & 7.2 & 0 & 84.6 & 11.8 \\
\hline $\begin{array}{c}\text { Local lists } \\
2015\end{array}$ & 16.7 & 0 & 81 & 14.7 \\
\hline
\end{tabular}


Table 2 Average share of seats won by local lists in 2015 considering corruption, inequality and legacy of regionalist parties (and comparison with 2011)

\begin{tabular}{|l|l|l|}
\hline & \multicolumn{2}{|c|}{ Average seat share won by local list } \\
\hline Contexts & $\mathbf{2 0 1 1}$ & $\mathbf{2 0 1 5}$ \\
\hline Corruption & 6.6 & 15.52 \\
\hline No & 7.9 & 18.74 \\
\hline Yes & 1.3 & $3.32^{* * *}$ \\
\hline $\begin{array}{l}\text { Difference (absolute } \\
\text { value) }\end{array}$ & 7.2 & 18.41 \\
\hline Inequality & 7.4 & 15.53 \\
\hline Low Inequality & 0.2 & $2.88^{* *}$ \\
\hline High Inequality & 6.4 & 16.39 \\
\hline $\begin{array}{l}\text { Difference (absolute } \\
\text { value) }\end{array}$ & 8 & 17.05 \\
\hline Regionalist Party & $1.6^{*}$ & 0.66 \\
\hline Weak legacy & & \\
\hline Strong legacy & $\begin{array}{l}\text { Difference (absolute } \\
\text { value) }\end{array}$ & \\
\hline
\end{tabular}

${ }^{*} \mathrm{p}<0.1 ; * * \mathrm{p}<0.05 ; * * * \mathrm{p}<0.01$. Independent samples T-tests (equal variances assumed). 
Table 3 Multivariate Linear Regression (OLS) explaining the success of local/civic/nonpartisan lists in Spanish Municipalities.

\begin{tabular}{|c|c|c|}
\hline & Model 1 & Model 2 \\
\hline H1. Corruption & $\begin{array}{l}2.7 * * \\
(1.3)\end{array}$ & $\begin{array}{l}0.97 \\
(1.05)\end{array}$ \\
\hline H2. Inequality & $\begin{array}{l}-0.29 * * \\
(0.13)\end{array}$ & $\begin{array}{l}-0.25^{* * *} \\
(0.1)\end{array}$ \\
\hline H3. Regionalist mobilisation & $\begin{array}{l}0.01 \\
(0.03)\end{array}$ & $\begin{array}{l}0.02 \\
(0.03)\end{array}$ \\
\hline Population size (log) & $\begin{array}{l}-1.45^{* *} \\
(0.69)\end{array}$ & $\begin{array}{l}0.85 \\
(0.56)\end{array}$ \\
\hline Per capita income $(\log )$ & $\begin{array}{l}15.46 * * * \\
(4.09)\end{array}$ & $\begin{array}{l}10.6^{* * *} \\
(3.2)\end{array}$ \\
\hline Internet connections & $\begin{array}{l}0.21 \\
(0.16)\end{array}$ & $\begin{array}{l}-0.01 \\
(0.13)\end{array}$ \\
\hline Izquierda Unida & $\begin{array}{l}-0.07 \\
(0.07)\end{array}$ & $\begin{array}{l}0.09 \\
(0.07)\end{array}$ \\
\hline Podemos & $\begin{array}{l}0.62 * * * \\
(0.25)\end{array}$ & $\begin{array}{l}0.44 * * \\
(0.2)\end{array}$ \\
\hline Local lists 2011 (legacy) & --- & $\begin{array}{l}0.75^{* * *} \\
(0.05)\end{array}$ \\
\hline Constant & $\begin{array}{l}-21.33 * * \\
(10.74)\end{array}$ & $\begin{array}{l}-15.38 \\
(7.94)\end{array}$ \\
\hline $\mathbf{N}$ & 661 & 661 \\
\hline R-squared & 0.1 & 0.41 \\
\hline
\end{tabular}

${ }^{*} \mathrm{p}<0.1 ; * * \mathrm{p}<0.05 ; * * * \mathrm{p}<0.01$. Robust standard errors in brackets. 